Per Aage Brandt: Kørlighedens semiotik, Århus, Sjakalen, 1983. Inge Houmann: Nihilismen, København, Borgen, 1983.

Siden den høviske kærligheds opdukken ved de middelalderlige hoffer har der været meget juristeri omkring kærligheden, især når den ikke bare rettedes mod ridderens dame og herskerinde, men blev edsvoren troskab til mere udviskede figurer som Kvinden, Fyrsten, Staten eller Magten. Når der tænkes i kontrakter kan det ligefrem være svært at holde juristeri og kærlighed ude fra hinanden. Inden for den sidste snes år er der imidlertid med semiotikken fremkommet en lidt anden måde at tænke over kontraktualiteten på - hos f.eks. Greimas er det en, ganske vist intuitiv, fornemmelse for at der må være nogle minimale betingelser til stede $i$ enhver form for kommunikation, hvad man kan formalisere i forskellige former for kontrakter. Dermed har Greimas, ligesom "strukturalisterne" som sădan, pådraget sig vrede og forargelse fra alle de, som nægter at tro på at mennesket i sproget, mindst af alt, kan underlægges kontrakter, hvadenten de er af normativ art eller drejer sig om nødvendige betingelser. Den slags gælder måske i "naturen", det gælder måske også i den samfundsmæssigtøkonomiske aktivitet, men ikke i sproget! "Strukturalismens" modstandere har derfor haft travlt med at kritisere den som en scientistisk reduktionisme, en ahistorisk determinisme osv. Eller rettere har kritikken haft denne form: videnskabeligt betragtet kan det måske være berettiget at tale om kontrakter og andre lovmæsigheder i sproget, men så snart menneskene bare mødes for at snakke og tale sammen, gælder den videnskabelige problematik ikke, og hvis menneskene alligevel ikke kan tale fuldstændigt frit og autentisk sammen, er det et politisk problem - det er "censur", "krænkelse af ytringsfrihe- den" og må kritiseres i "den herredømmefri kommunikations" navn. Denne manøvre, at tilkende sprogvidenskaberne er særlig, afgrænset berettigelse og samtidig åbne en politisk-utopisk dimension ved siden af, genfinder man f.eks. hos Habermas.

At semiotikken ikke kan reduceres til en scientistisk problematik er måske en af hovedpointerne $i$ Per Aage Brandts Kœrlighedens semiotik. I sproget er der noget der er umuligt, men det er ikke blot et spørgsmål om videnskabeligt at bestemme nogle determinismer, som sprogudøvelsen må adlyde på samme måde som legemer i "naturen" må adlyde tyngdeloven. Derfor hedder det også: de talende subjekter møder sproget som en "falles skabne". Sproget er derfor heller ikke et eller andet redskab, som subjektet, alt efter omstændighederne, har til dets rådighed eller ikke, på samme måde som man råder over blyanter eller tekstbehandlingsanlæg eller $i$ det hele taget adgang til trykning og offentliggørelse - snarere er sproget det, som gør de talende til subjekter, "skiller" dem ad, gør dem forskellige og gør at ingen snakker helt det samme sprog.

Man kan i de nyere former for semiotik hele tiden støde på denne opmærksomhed over for dette "møde" med sproget - "at tage ordet" er ikke så tilforladeligt som det lyder; nogen tager det selv, alt for gerne, andre skal have det tildelt, nødtvungent, og kommer det først i gang, risikerer alle at det ene ord tager det andet, og tager den talende med sig. Når sproget på denne måde bliver medrivende, kan det så imidlertid nok være at man finder videnskaben frem igen, også selv om man er kritisk over for strukturer og kontrakter; nu, hvor sproget og den talende kommer for tæt på hinanden, vil man godt indrømme at der må være nogle minimale betingelser, som ikke må overtrædes. F.eks. gælder der så nogle regler for hvor tæt forholdet til sproget må være, hvis det 
skal være "videnskab", men det er uskrevne regler, som helst ikke skal nedskrives. Dette har bogens forfatter således fået påpeget (jvf. anmeldelsen af sandheden, sctningen og døden i dette nummer), f.eks. beskyldes han for at "glide" i citaterne, men sige nærmere hvad det vil sige, og hvordan man undgår det, kan ingen, og sikkert er der ikke andet at stille op end pedantisk juristeri, regler for brug af anførselstegn el. lign.

Denne kritik udsætter Per Aage Brandt sig næppe for med denne bog: skal man nemlig karakterisere den, må den nærmest kaldes en samling essays, hvormed ikke bare menes en litterær genre, men simpelthen: fors $\phi g$. Først og fremmest drejer forsøget sig om simplificering, klarhed, og modersmålpurister vil kunne finde den ene sætning efter den anden på ganske almindeligt, velklingende dansk - "klar tale", som næsten ikke kræver nærmere omtanke, som siger sig selv, som om den ikke blev sagt af nogen. I denne forstand vover essay'ene nogle hypoteser, nogle formelagtige sammenfatninger af semiotikkens udvikling inden for de sidste år. Et forsøg indebærer også en risiko for at mislykkes, måske lykkes klarheden og gennemsigtigheden ikke, måske er klarhedens pris udelukkelsen af træghed og modstand, så der ikke er andet end det klare hoveds rene energi tilbage. Klarhed er ogsă anstrengelsen med at lukke ørerne for det "uvæsentlige", støjen som forstyrrer tavsheden og stilheden - og trods anstrengelserne er det alligevel umuligt at forhindre at sprogets "uafrystelige materialitet" vælder frem og bringer uklarhed. Det er når det, som det hedder, dukker op som "diskursens magma" eller betydningerne fortættes og himlen falder ned på jorden. Her er det så mødet med sproget atter bliver skæbnesvangert, efter at have nydt den klare udsigt med forfatteren skilles vejene igen, ingen snakker alligevel helt det samme sprog. Den olympiske klarhed fra det ophøjede synspunkt brydes, det er betingelsen for disse essays' bjergvandring.
Det er vanskeligt at udforske magma, forsøger man at sondere i det v.h.a. boringer, smelter borene og borehullerne tilstoppes er der da ikke andet at gøre end at forvisse sig om dets eksistens gennem de periodevise vulkanske udbruds fakticitet, jordrystelserne og lavastrømmene, som man først kan nærme sig når de er størknede? Dette kan man ikke konkludere om sproget - i sidste instans viser det sig at sprogets materialitet altid er tekstlig, at sproget er noget der skrives, at strømmene følger baner og revner. Semiotikken bliver netop en videnskab om de figurer, der dannes derved, "en slags matematisering - uden egentlig matematik - af sprogets materialitet, dets massive tavsheder og tale". Semiotikken er altså ikke så meget en videnskab om talen eller "italesættelsen", i forlængelse af lingvistikken, omvendt heller ikke en præsentation og rehabilitering af oversete og undertrykte sprog, men netop en teori om skriften, en skrift, der, vel at mærke, tatoverer sig helt ind $i$ de talendes kroppe, spalter den talendes sprog i noget der vises frem offentligt og $i$ et andet sprog, subjektets rest, reservoir, reserverethed.

Som offentligt sprog, dvs. det tilstrækkeligt mange kan være fælles om, vil sproget være præget af knaphed, sproget er "for lille", som Nietzsche er inde på: det bliver som mønter, der slides i pengenes cirkulation, der er alt for snæver i forhold til varernes kredsløb, eller det bliver som begreberne, der metodisk reduceres, skematiseres og abstraheres fra det konkretes træge materialitet, for at vinde i klarhed og forståelighed.

Selv om Nietzsche kun ønskede sig få læsere, indså han tidligt at hans skæbne var at der skulle holdes offentlige forelæsninger, der skulle kaste lys i den hule, som hans filosofi er, ganske vist ikke i hjemlandet, men i Danmark, på Københavns Universitet, ved den europæiske kulturmissionær Brandes. Næsten 100 år efter sker det igen - nej, ikke ved Brandt, men ved en teolog, Inge Houmann. I 
disputatsen Nihilismen foreslås det at undersøge nihilismen ud fra sproget som Nietzsche forstår det, som en semiotisk nihilisme. Hvis man ellers får associationer i retning af absurdisme, værdikrise og antizaristisk terrorisme synes det ikke nogen dårlig ide at undersøge nihilismen v.h.a. semiotikken, men man opdager hurtigt at semiotik og semiotik er to ting. Ud fra lange citater af Nietzsche, efterfulgt af kommentarer og ingen citatglidning, bortset fra at Russel og Habermas, som det der kommer nærmest semiotikken, bruges som nøgle til Nietzsches semiotik, ud fra denne akademiske form forklares sammenhængen mellem sprog og 'nihil' som dette at sproget ikke adækvat dækker virkeligheden, det skildrer den utroværdigt, det postulerer mere end det konstaterer, det er løgn og fiktion, i erkendelsesteoretisk forstand, hvor løgn og fiktion er ren indbildning uden jordforbindelse, og ikke i semiotisk forstand, som et spørgsmål om sprogets manifestationsmåde. Det er en disputats $i$ et stivnet, skematisk og akademisk sprog, om Nietzsche som kritiker af et stivnet, skematisk og akademisk sprog. Det er en disputats, som fortæller at Nietzsche gik ind for et levende, kreativt sprog, og selv om man kan dele Houmanns sympati for Nietzsches stil, behøver man jo blot at åbne Nietzsche selv for at finde ud af det!

Det er virkelig to vidt forskellige former for semiotik, der er tale om: på den ene side en mistro til sproget, som uden selvironi i tør disputatsform taler om alt det sproget ikke kan tale om, og på den anden side en kærlighed til sproget, der med god samvittighed taler, selv om der er meget sproget ikke kan tale om.

\section{Erling Hommelgaard}

\section{DET GÅDEFULDE ER DET ANDET KøN}

Marie-Francoise Hans og Gilles Laponge (ed.): Mcends pornografi, kvinders erotik, Modtryk 1983.

Nu har Modtryk også udgivet sin kønsbog. Den handler om Evelyne og Christiane og Josée, og Laure og Claudine og Maria og en masse andre. Den egentlige sigte med bogen var pornografien og kvindernes forhold til det, men så kom bogen til at handle om utrolig mange ting, nemlig seksualiteten. Kvindernes svar er for det meste forudsigelige og uden overraskelser, således at havde man først læst "klassikerne" indenfor genren, ville man med lidt fantasi og opfindsomhed snildt være i stand til at konstruere svarene som rent skrivebordsarbejde - måske! Enkelte af de mere intellektuelle svar er åbenlyst fortænkte og retorisk indstuderede efter en freudiansk model med overtoner af en simuleret almenhed i replikkerne og meningerne. De fleste svar er dog præget af en umiddelbar "ægthed" og forfatterne præsenterer dem uberørte, hvilket gør bogen til endnu en samling empirisk vigtigt bekræftelsesmateriel på en masse spekulationer - bogen er en slags fænomenologisk dokumentmappe til arkivariske konsultationer. Der er dog et par originale blandt de interviewede! den med at blive ophidset af kirkemusik havde jeg endnu ikke hørt, selv om den måske er oplagt, og så var der en anden der frydede sig over prut og den slags lystig børnehavenostalgi og det mindede mig så om en jeg kendte...

I disse tider hvor kønsdebattens inderlighed har opnået salonværdighed og er blevet legitim underholdning, selv for venstrefløjen, kan man godt hente et par gode plots $i$ bogen. Der er for eksempel en enkelt kvinde, eller var der to?! som tilsyneladende misundte mandskønnet dets smud- 